\title{
Institutionalized Barriers and Supports of Female Athletic Directors: A Multilevel Perspective
}

\author{
Elizabeth A. Taylor \\ Temple University \\ Janelle E. Wells \\ University of South Florida
}

\begin{abstract}
Despite an increase in participation rates among girls and women across all levels of sport, women are still underrepresented in leadership positions. Less than $10 \%$ of National Collegiate Athletic Association (NCAA) Division I Athletic Directors (ADs) are female. The current study examined the supports and barriers of 10 NCAA Division I female ADs. Using institutional theory to frame the research, through semistructured interviews barriers and supports were categorized using a multilevel approach model (i.e., macro, meso, and micro). The multilevel approach allows readers to see how factors shape and are shaped by one another. Results revealed macro factors such as power, hegemonic masculinity, inclusive environments, stakeholder expectations, and institutional gender discrimination. Meso factors included occupational segregation, family-work life, organizational demography and culture. Micro factors included self-efficacy, gender socialization, career intentions, self-limiting behaviors, human and social capital. Overall, three factors emerged as support-only factors: inclusive environments, human and social capital, while seven factors materialized as barrier-only factors. These results have both theoretical and practical application opportunities for individuals, organizations, and society.
\end{abstract}

Keywords: gender, leadership, sport, collegiate athletics

Over the past 40 years we have seen a steady increase in opportunities for participation in sport for females (Acosta \& Carpenter, 2014; Lapchick, 2015). From the grassroots level to the professional ranks the number of female athletes participating in sport increased significantly (Acosta \& Carpenter, 2014; Lapchick, 2015; National Federation of High School Associations, 2014; Smith \& Wrynn, 2013). Despite these increases in opportunities for participation, there has not been

Taylor is with the Department of Sport \& Recreation Management, Temple University, Philadelphia, PA. Wells is with the Department of Sport Management, University of South Florida, Tampa, FL. Address author correspondence to Elizabeth Taylor at elizabeth.taylor@temple.edu. 
the same growth of females working in coaching or athletic administration (Acosta \& Carpenter, 2014; Lapchick, 2015). For example, before the implementation of Title IX, 90\% of women's teams were coached by women (Acosta \& Carpenter, 2014); however, as men began seeking coaching positions of women's teams and administrative positions in women's athletics once the National Collegiate Athletic Association (NCAA) began sponsoring championships for women and universities increased funding for women's sports we started to see a decline in the percentage of female coaches and administrators (Longman, 2014). Today, less than $25 \%$ of athletic departments are run by females across all three divisions of the NCAA, and that percentage drops to less than $10 \%$ at the Division I level. In general, $11 \%$ of athletic departments do not have a female in their athletic administrative structure (Acosta \& Carpenter, 2014).

Due to the masculine nature of the sport the majority of leadership positions within the sport industry (e.g., head coaches, ADs) are held by men (Lapchick, 2015; Whisenant, Pedersen, \& Obenour, 2002). One potential reason so many leadership positions are held by men is because leadership skills are often constructed in terms of masculinity, creating a situation where females are eliminated from the selection process of jobs that hold leadership duties (Hovden, 2000). Further, females have been stereotyped as less capable leaders than males (Embry, Padgett, $\&$ Caldwell, 2008). As such, these engrained social behaviors and normative systems have created the social order (Greenwood, Oliver, Sahlin, \& Suddaby, 2008) and institutionalization of male sport leaders.

Given the pervasive underrepresentation and decline of females in sport leadership positions, several researchers have presented potential explanations. Researched reasons include gender role attitudes and stereotypes of leaders (Burton, Barr, Fink, \& Bruening, 2009; Grappendorf, Pent, Burton, \& Henderson, 2008), homologous reproduction, (Lovett \& Lowry, 1994; Stangl \& Kane, 1991), combining of athletic department managements (Grappendorf \& Lough, 2006; Sagas \& Cunningham, 2004), family work balance (Inglis, Danylchuk, \& Pastore, 2000), sexism and homophobic exclusion (Cahn, 1994; Walker, \& Melton, 2015), male hegemony (Norman, 2010; Walker, \& Sartore-Baldwin, 2013; Whisenant et al., 2002), resistance to job changes (Carpenter \& Acosta, 1992), promotion and career satisfaction (Sagas \& Cunningham, 2004), and rate of advancement (Hancock, \& Hums, 2016; Whisenant et al., 2002). While these studies have contributed to the literature, by and large, each study has a limited single level of analysis. More recently, researchers have begun using a multilevel framework (i.e., macro, meso, and micro level) to address underrepresentation in coaching positions (Cunningham, 2010; LaVoi \& Dutove, 2012) and women, in general, in sport leadership positions (Burton, 2015). Subsequently, the purpose of this study was to use a multilevel approach to explain the supports and barriers experienced by female NCAA Division I ADs.

To frame this multilevel approach DiMaggio's (1988) institutional theory was used. Institutional theory, discussed in more detail below, emphasizes the cultures adopted within organizations and how they influence the experiences of the employees (Konrad, Yang, \& Maurer, 2016). When examining the experiences of female ADs, institutional theory may help reveal beliefs, norms, and values that have influenced the culture, policy, and rituals which impact the way intercollegiate athletics function. Since the domain of intercollegiate athletic administration is a 
system that has favored men over women (LaVoi \& Dutove, 2012), it is suggested a male AD has been legitimated and maintained, as the "way things are to be done" (Scott, 1987, p. 496). Thus, by exposing multilevel barriers and supports of female ADs, the hope is to expose the social processes by intertwining all three levels (i.e., macro, meso, and micro).

\section{Theoretical Framework}

Previous research on the underrepresentation of women in coaching and administrative positions has been conducted using numerous theoretical perspectives. Although this research presents distinct findings, it shares the commonality of barriers based on gender (Walker \& Sartore-Baldwin, 2013). These barriers can perhaps be explained by institutional theory and the adoption of discriminatory norms in male dominated industries such as sport.

\section{Institutional Theory}

Institutional theory highlights the standard, or normal, milieu and behaviors within an organization (Konrad et al., 2016). These environments include laws, rules, and regulations as well as professional norms and ethics set forth by the organization and the individuals who work within the organization (Scott, 1995). These rules, regulations, and norms can take many years to create and standardize. When organizations adopt these rules, regulations, and norms they are showing conformity to social norms and demonstrating their legitimacy (Konrad et al., 2016), which makes it a useful tool for assessing behaviors within sport organizations (Washington \& Patterson, 2011; Walker \& Sartore-Baldwin, 2013).

Institutional theory has been used to examine a number of issues in intercollegiate sport including diversity and inclusion (Cunningham 2008), hegemonic masculinity (Walker \& Sartore-Baldwin, 2013), and institutionalization (Washington \& Patterson, 2011). Sagas and Cunningham (2005) found African-American coaches expressed lower scores in career satisfaction, fewer promotions, and less organizational proximity to the head coach position as compared with white coaches although levels of human and social capital were similar, which provided support for institutional discrimination. Washington and Patterson's (2011) institutional review revealed how "diversity in society affects diversity in sport" (p. 10) and called for further attention to the micro and macro level analyses. Further, results from Walker and Sartore-Baldwin (2013) supported tenets of hegemonic masculinity and cognitive institutionalization in men's basketball. More specifically, these male coaches acknowledged a culture that was hyper-masculine, resistant to change, and gender exclusive of women coaching men's basketball (Walker \& Sartore-Baldwin, 2013).

In the male-dominated industry of sport, at the intercollegiate level, most AD positions in NCAA Division I athletic departments are held by men, and the number of men coaching women's sports is continuously growing (Acosta \& Carpenter, 2014). These organizational norms shape the culture of sport organizations. As such, the division between males and females creates a gendered power dynamic in sport that is unmatched. For this reason, gender inequity operates as an institutional practice in sport organizations (Cunningham, 2008). As previously mentioned, when looking at organizational demography is sport organizations, men dominate leadership positions. 
Moreover, women working in administrative positions within athletic departments are often put in charge of the "soft" areas of the department such as academic advising, life skills, and women's sports (Grappendorf et al., 2008; Hoffman, 2010). This placement limits advancement opportunities for women because they are unable to gain experience in fundraising or managing a successful football program which are two areas most valued by hiring AD committees (Hardin, Cooper, \& Huffman, 2013). Women may also face discrimination when working in male-dominated industries. It is not uncommon for women working in male-dominated industries to attract increased attention, be evaluated more critically, and experience less support, especially when they are new to their organization (Embry et al., 2008; Kanter, 1977; Walker \& Sartore-Baldwin, 2013). Specific to the sport industry, women face unequal assumption of competence, hiring from a principle of similarity, homophobia, and lack of female mentors (Kamphoff, 2010; Kilty, 2006). Females working in sports often describe experiencing difficulty working in a hostile, male-dominated environment (Norman, 2010).

In addition, women in the sport industry may face difficulty getting hired due to homosocial reproduction. Homosocial reproduction, or hiring from a principle of similarity, refers to the phenomenon where individuals prefer to work with those who are similar to themselves (i.e., individuals who are similar in race and gender, and have a similar cultural background), and therefore recruit and hire those individuals to their organization (Ramirez, 2004). Research has found that in-group members are more likely to be selected as leaders in an organization than out-group members, which further illustrates homosocial reproduction (Gaertner, Mann, Murrell, \& Dovidio, 1989).

Homosocial reproduction in sport causes challenges for women to get hired into decision-making positions due to male managers wanting to hire employees similar to themselves, as well as the need for high levels of trust and interdependence. Hiring from a principle of similarity can be easily illustrated within intercollegiate athletics. Before the implementation of Title IX, when athletic departments were divided into separate men's and women's athletic departments run by two different ADs, the AD of the women's athletic department was often female (Acosta \& Carpenter, 2014). This often occurred due to homosocial reproduction, and the fact that funding for the women's athletic department was limited making the position less desirable. However, in recent years there has been an increase in funding for women's sports and salaries of coaches of women's teams, making these positions more desirable thus increasing the number of men trying to break into coaching women's sports (Acosta \& Carpenter, 2014).

\section{Multilevel Perspective}

Previous research on coaching and athletic administration have investigated the lack of diversity in the sport industry from a multilevel perspective (Burton, 2015; Cunningham, 2010) due to the fact that "sport organizations are multilevel entities that both shape and are shaped by myriad factors" (Cunningham, 2010, p. 396). Utilizing a multilevel framework allows investigators to capture the imbedded complexity of an organization's culture (Klein \& Kozlowski, 2000). A complete multilevel analysis will examine issues from both a top-down and bottom-up approach, giving a more complete view of the organization (Klein \& Kozlowski, 2000). The multilevel perspective also gives a more comprehensive view that allows for the greatest levels of 
understanding, explanation, and problem solving (Allison, 1971; Bolman \& Deal, 2003). Unlike previous research, which has looked at diversity issues from individual levels (i.e., structural or individual), a multilevel perspective allows researchers to see how the various levels interact within the organizational system (Bolman \& Deal, 2003; Kozlowski \& Klein, 2000). The multilevel model used in this study is comprised of three levels: macro-level, meso-level, and microlevel. Factors in this multilevel model do not operate individually, however, different factors influence and are influenced by one another in a reciprocal manner (Chelladurai, 2014).

Macro-Level Perspective. At the macro-level political climate, institutional practices, and stakeholder expectations are assessed (Cunningham, 2010). When examining the issue of the underrepresentation of women in athletic administration positions from a macro-level, sport must be recognized as a gendered institution (Burton, 2015). From an early age male athletes learn that they are supposed to exhibit the highest levels of masculinity to be successful athletes (Messner, 1992). On the other hand, based on traditional societal norms created through patriarchal views, females are taught they are supposed to exhibit characteristics that are traditionally thought of as feminine (e.g., emotional, empathetic, needy), while participation and success in sport are often frowned upon (Kolnes, 1995).

Meso-Level Perspective. When utilizing a multilevel model, research at the meso-level focuses on factors that operate in organizations and the way decisions are made (Cunningham, 2010). Further, this level of analysis looks at the ways in which structures and processes serve to perpetuate the underrepresented in leadership positions within intercollegiate athletics (Cunningham, 2010). The male dominated nature of the sport industry influences organization culture. In male-dominated organizations and industries, women and racial minorities are perceived as organizational intruders, potentially reducing the benefit of being part of the hegemonic group (i.e., white men) (Bergman \& Henning, 2008). This divide within the organization allows for classification based on social identity, creating an ingroup comprised of white men and an outgroup comprised of women and racial minorities (Cunningham \& Sagas, 2005). This creates a climate that is unwelcoming for women. Women working in these male-dominated industries often times become expecting of this type of behavior.

Access and treatment discrimination operate at the organizational (i.e., meso) level and may negatively impact women's abilities to enter into or be successful in leadership positions in sport organizations (Burton, 2015). Access discrimination occurs when members of certain groups are unable to enter into organizations due to exclusion, whereas treatment discrimination occurs after entering the organization (Greenhaus, Parasuraman, \& Wormley, 1990). In treatment discrimination a member of a certain group receives fewer recourses then they deserve (Greenhaus et al., 1990). Researchers have found both access and treatment discrimination to be present in intercollegiate athletic departments. In intercollegiate athletics, and other sport organizations, women may face access discrimination as an unequal assumption of competence due to gender, which may lead them to not get offered a job they are qualified for (Maume, 1999). On the other hand, treatment discrimination may come in the form of offering subgroup members fewer opportunities, resources, or rewards (e.g., female coaches fewer resources than male coaches (Greenhaus, Parasuraman, \& Wormley, 1990). 
Microlevel Perspective. At the microlevel, research focuses on the individual (i.e., female $\mathrm{AD}$ ) and how they make sense of their experiences and understand power, procedures, and policies that operate at the organizational level (Burton, 2015). Scholars have attempted to gain understanding into forces that served as barriers for entry into and advancement in the sport industry. In addition to experience, barriers such as unequal assumption of competence, homophobia, lack of female mentors (Kamphoff, 2010; Kilty, 2006), early departure from the profession due to lack of time and support, family responsibilities, and burnout (Kamphoff, 2010) have hindered females in intercollegiate coaching and athletic administration.

In addition, the microlevel explores differences that exist in human and social capital based on gender. An individual accrues human capital through attaining education, job training as well as on the job experiences (Sagas \& Cunningham, 2004). Furthermore, an individual can attain social capital through establishing a network of relationships with supervisors, peers, and subordinates (Sagas \& Cunningham, 2004). The impacts of social capital have been found to negatively affect women's career aspirations within intercollegiate athletics (Cunningham \& Sagas, 2002). Differences in career paths are thought to vary based on ability and schooling across individuals, and the progression of occupations of an individual.

\section{Method}

The purpose of the current project was to explain the supports and barriers experienced by female NCAA Division I ADs. Researchers were interested in gaining understanding of the inner experiences and thoughts of participants, so a phenomenological qualitative research design was used (Corbin \& Strauss, 2008; Gratton $\&$ Jones, 2004). The phenomenological nature of the study allowed for participants to tell their story through interviews and allow themes to emerge (Gratton \& Jones, 2004). The phenomenological approach was chosen because it allowed for meaning to be drawn from the interviews, and then placed into themes to construct the narrative. The meanings of those themes are then presented later, in the results and discussion (Dittmore, 2011).

Interviews allow researchers to ask questions and listen while participants respond, thus grounding interviews in discussion (Rubin \& Rubin, 1995). The participant's "work life" (i.e., supports and barriers in the workplace) was the central focus of this study, so interviews were used to allow the researcher entrance into the participant's perspective and create meaning and themes from experiences that have occurred in the participants lives (Yin, 1994). Due to the nature of the data collection process, interviews also allowed for probing and clarification of responses via follow up questions (Gubrium \& Holstein, 2001). Interview questions were crafted to gain more information on the barriers and supports present for women working as Division I ADs.

\section{Participants}

Semistructured interviews were conducted with 10 female Division I ADs in the Fall 2013 athletic season. This study used purposive sampling because of the limited number of NCAA Division I female ADs at the time of data collection $(N=34)$. The participants were purposefully selected because it was believed they would be 
able to provide the most accurate information to address the purpose of the study (Creswell, 2013). Participants offered unique perspectives due to different demographic characteristics including relationship status, years in position, conference affiliation, and football sport sponsorship. All of the participants had experience and expertise as a female AD making them acceptable subjects (Andrew, Pedersen, \& McEvoy, 2011).

The participants had an average age of 55-years old and had been an AD for an average of nine years (see Table 1 for full demographic information). The range of experience was from half a year to 21 years at the time of data collection. Five

\section{Table 1 Participant Demographics}

\begin{tabular}{|c|c|c|c|c|c|}
\hline Participant & $\begin{array}{l}\text { Occupational } \\
\text { Tenure (years) }\end{array}$ & Education & $\begin{array}{l}\text { College } \\
\text { Athlete }\end{array}$ & $\begin{array}{l}\text { College } \\
\text { Coach }\end{array}$ & $\begin{array}{l}\text { Division I } \\
\text { Level }\end{array}$ \\
\hline A & 16 & $\begin{array}{l}\text { B.S. Education } \\
\text { M.S. Sport Admin }\end{array}$ & Yes & Yes & FBS \\
\hline B & 24 & $\begin{array}{l}\text { B.S. PE } \\
\text { M.A. Health \& } \\
\text { PE }\end{array}$ & Yes & Yes & $\begin{array}{l}\text { DI no } \\
\text { football }\end{array}$ \\
\hline $\mathrm{C}$ & 10 & $\begin{array}{l}\text { B.S. PE } \\
\text { M.ED. Sport Psy- } \\
\text { chology } \\
\text { MBA }\end{array}$ & Yes & Yes & $\begin{array}{l}\text { DI no } \\
\text { football }\end{array}$ \\
\hline $\mathrm{D}$ & 26 & $\begin{array}{l}\text { B.S. PE } \\
\text { M.S. Athletic } \\
\text { Admin }\end{array}$ & No & Yes & FBS \\
\hline E & 26 & $\begin{array}{l}\text { B.S. Political Sci- } \\
\text { ence } \\
\text { MBA }\end{array}$ & Yes & Yes & $\begin{array}{l}\text { DI no } \\
\text { football }\end{array}$ \\
\hline $\mathrm{F}$ & 19 & $\begin{array}{l}\text { B.S. Business } \\
\text { Administration } \\
\text { M.A. Education }\end{array}$ & No & Yes & FCS \\
\hline G & 9 & $\begin{array}{l}\text { B.S. Psychology } \\
\text { M.A. Sport } \\
\text { Administration }\end{array}$ & Yes & No & $\begin{array}{l}\text { DI no } \\
\text { football }\end{array}$ \\
\hline $\mathrm{H}$ & 19 & $\begin{array}{l}\text { B.S. Kinesiology/ } \\
\text { Social Studies }\end{array}$ & Yes & Yes & FBS \\
\hline I & 30 & $\begin{array}{l}\text { B.S. PE } \\
\text { M.S. Sport Mgmt } \\
\text { MBA }\end{array}$ & Yes & Yes & FBS \\
\hline K & 15 & B.A. English & Yes & Yes & FBS \\
\hline
\end{tabular}

Note. * Self-Identified, PE-Physical Education 
of the respondents were married and one had a partner. Eight were former studentathletes, and nine had coaching experience. An examination of the demographic characteristics reveals a similar profile of all of the respondents. Nine of the 10 women were intercollegiate coaches and/or student-athletes before they began their careers in athletic administration, and eight of the 10 hold a master's degree. The typical post coaching career path move of the participants was in administrative role as an assistant AD, then the Senior Woman Administrator (SWA) to senior associate AD. That was followed by the accession to AD. These women represented athletic departments across all subdivisions of Division I athletics (i.e., Football Bowl Subdivision (FBS), Football Championship Subdivision (FCS), and Division I No Football).

\section{Procedures}

The small population of female Division I ADs also dictated the decision to use a qualitative design (Gratton \& Jones, 2004). An e-mail inquiry was sent to 10 females ADs asking for participation. These 10 women were selected due the NCAA divisional status of the institution they were employed by at the time of the interview. Researchers wanted to interview women at the Football Bowl Subdivision (FBS), Football Championship Subdivision (FCS), and Division I no football level. Due to the fact that there are a greater number of women working at the FCS and Division I no football level, the researchers were purposeful in who they contacted in attempts to get a representative sample. Initial e-mails were sent to the AD's school e-mail account and invited the women to participate in an interview. All 10 of the initial ADs contacted agreed to participate. All of the participants were considered experts in the field of athletic administration because they had numerous years of experience at different levels throughout athletic departments around the country (Andrew et al., 2011).

The utilization of semistructured interviews allowed for participants to fully explain their unique experiences, supports, and barriers in the workplace. The open-ended nature of the interview questions allowed participants to put their perceptions, emotions, and feelings into words. Follow up questions were also used based on the responses of the participants allowing for further clarification and increased detail. Topics of questions included: career aspirations (e.g., Tell me about how you got to where you are?; Was being a collegiate AD your career aspiration?); challenges of being an AD (e.g., What is your biggest challenge as a female AD?), career advice (e.g., What advice would you give to a female wanting to pursue a career in intercollegiate athletics?); and interactions with colleagues (e.g., How do you interact with male coaches?), and mentoring (e.g., Do you feel a duty to mentor women trying to break into or advance in intercollegiate athletics?). The interview guide included questions that were asked to all participants as well a question that was specific to the sublevel (i.e., FBS, FCS, and Division I No Football) of the athletic department the participant was employed. See Table 2 for a full list of interview questions.

Interviews were conducted via telephone and were audio recorded for transcription purposes. Participants were initially asked to participate in a $30 \mathrm{~min}$ interview due to the lack of accessibility and availability of ADs (Hardin et al., 2013). The average length of the interviews was $27 \mathrm{~min}$. Since researchers should 


\section{Table 2 Interview Guide}

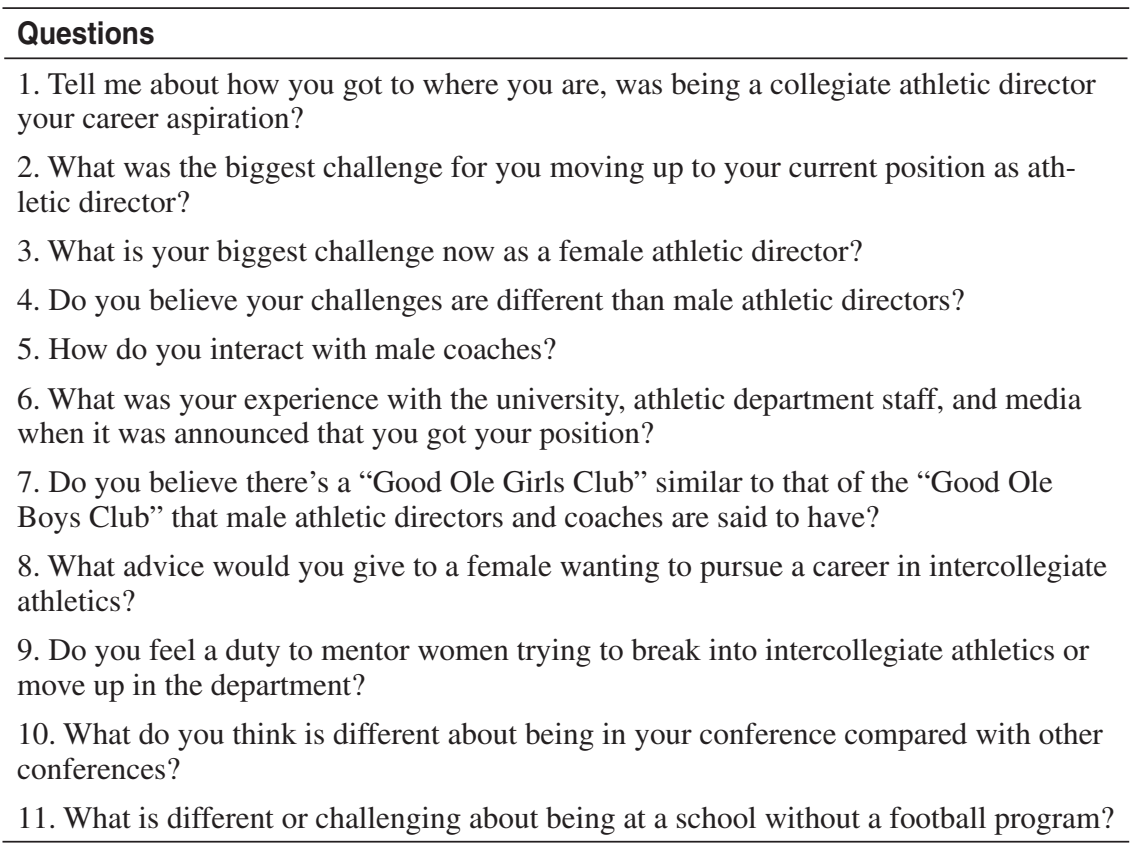

strive to achieve data saturation, which occurs when new categories or themes stop emerging from the data (Corbin \& Strauss, 2008), the researchers deemed saturation occurred after 10 interviews, which is similar to other sport researchers small sample sizes (see Sutherland, Kowalski, Ferguson, Sabiston, Sedgwick, \& Crocker, 2014; Owton, Bond, \& Tod, 2014).

\section{Analysis}

Following the completion of the interviews, interviews were transcribed and arranged for analysis by researchers. In addition, transcripts were sent back to participants for member checking. Member checking allows participants to read the transcript from their interview to ensure the transcript accurately depicts their responses and is a step in the validation process of qualitative research (Andrew et al., 2011; Gratton \& Jones, 2004). Following member checking two researchers individually coded the transcripts for themes and then met to discuss their findings. Researchers reached agreement on all themes across the three levels of the analysis. A constant comparative data analysis method was used. When using constant comparative methods one section of the data are compared with another to uncover similarities and differences (Merriam, 2009). Themes of the study emerge when similar dimensions of data are grouped together. Exposing patterns in the overall goal of this type of data analysis. "Meaningful and manageable themes" were formed through grouping of quotes of related experiences, supports, or barriers discussed by 
participants (Patton, 1987, p. 150). Themes and codes were discovered inductively, rather than deductively; during inductive analysis researchers make inferences from many elements of discourse from the interviews (Lindlof \& Taylor, 2011).

Similar methods have been used when conducting research on women working in intercollegiate athletic departments, however, research on female ADs is sparse. Hoffman (2010) used comparable methods to interview SWAs to gain understanding into their influences when promoting women to leadership position in athletic administration. In addition, Grappendorf and her colleagues (2008) used similar methods in a study on SWA's perceptions of decision making to provide detail and strength through direction quotation of their participants.

\section{Results and Discussion}

Similar to LaVoi and Dutove's (2012) process, supports and barriers of NCAA Division I female ADs emerged and were categorized by context into three levels: macro, meso, and micro. The results begin with a review of the distal level of the female AD's experiences and move to the most proximal individual level of female AD's experiences (see Figure 1).

\section{Macro-Level Factors}

At the macro-level sport is recognized as a gendered institution where processes operate in a hegemonic masculine norm (Burton, 2015), history and habits become

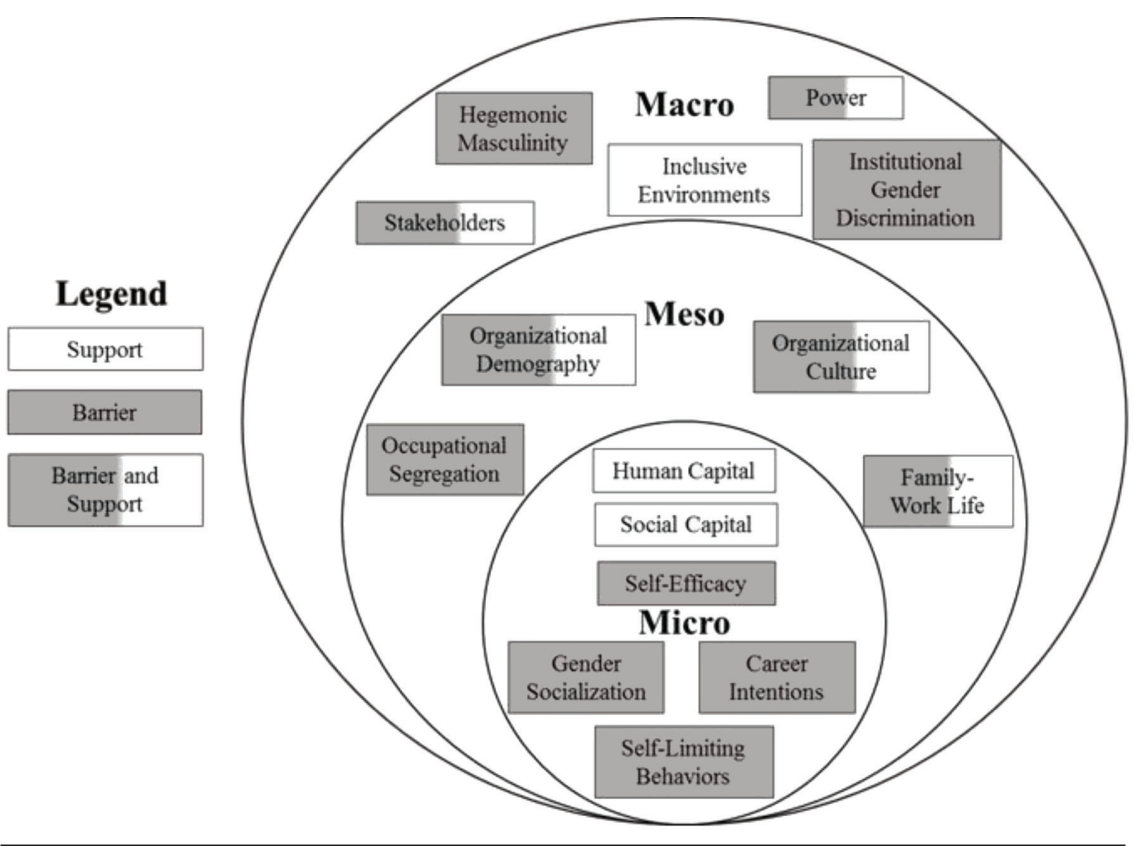

Figure 1 - A multilevel model of NCAA Division I female ADs supports and barriers. 
institutionalized(Scott, 1987), and gender inequity develops into an institutionalized practice (Cunningham, 2008).

Macro-level supports. Similar to Shaw and Frisby (2006) revelation that power influences women's experience in sport organizations, every participant recalled an influential moment in their career when a person of power encouraged them to advance in the field. Establishing relationships with a person of power, referred to as a key constituents, has assisted participants' career advancement. Key constituents are stakeholders who can influence and are influenced by organizational actions (Freeman, 1984), and they are instrumental in changing a cognitive institution (Leblebici, Salancik, Copay, \& King, 1991). Intercollegiate athletic department constituents included, but are not limited to, alumni, faculty, staff, donors, students, student-athletes, and administrators of the institution. For our participants, in particular, one of the most influential stakeholders to a female athletic administrator's career has been a current male AD. Working for a male $\mathrm{AD}$ was the norm for all of our participants. In fact, it is important to note that none of the participants had ever worked for a female AD throughout their career, which reinforces how gender inequity has been operating as an institutionalized practice in sport organizations (Cunningham, 2008), particularly in intercollegiate athletic departments. Despite these gender inequities in sport leadership, the newly hired AD, Gabby "was grateful to have a wonderful boss at [previous institution] who let me be a part of everything. He involved me, depended on me for things that helped me understand what it meant [to be an AD]." In addition, seven-year veteran, Faith's former AD asked her "What do you want to do?," and she said:

I'm sick of working behind the scenes, I want to work with student-athletes and he looked at me and said well, we don't have a life skills program do we? And I said, nope, and he said okay, you're [the] assistant AD, build the life skills program.

Hannah had a similar experience after 15 years coaching, and 10 as both a coach and athletic administrator when her AD came to her and said "Look, we'd really like for you just to do one job. You don't need to do both [coaching and administration] these jobs. I would prefer that you be senior associate AD and give up coaching, but it would be your choice."

Faith, Gabby, and Hannah all noted examples based on a relationship with a high-level organizational member. When an individual networks with a higher status constituent it provides greater access to expertise and can lead to higher status and career success (Forrest \& Dougherty, 2004). In addition, since women, at times, have been excluded from high-status networks, especially those above the glass ceiling (i.e., women who hold positions power that are typically held by men and unreachable for women) (Lyness \& Thompson, 2000). Such examples reveal how imperative it is for women to make connections with key constituents and higher-level organizational members to increase their access to resources, information, and influence (Seibert, Kraimer, \& Liden, 2001).Constituents across campus are also instrumental to one's career advancement in collegiate athletics. For example, Hannah recalled when an AD position came open "the current Provost had been associate Provost at [the name of my previous institution] for 11 years and had been on the athletic counsel. When he got here, the first position he had to hire was an AD [me]." 
Since institutions rely heavily on boosters and alumni for monetary support, and boosters serve on hiring committees, there is a perceived need that donors want to identify with the employed athletic personnel (Cunningham, 2010). Seven of the 10 participants mentioned support from these stakeholders. Gabby joked that "It's kind of funny because older male alums and donors, I've found, it's almost like they want to be a big brother or fatherly figure to you." Faith also has a "group of men, very, very wealthy in our community who want to see me succeed, which is very positive and I'm very grateful." Additionally, when six-year AD, Ellie, was promoted from within she received an overwhelming amount of support from a multitude of stakeholders. "There was an outpouring of well wished from current employees at the university, also from alumni and booster, from friends of mine, and colleagues, student-athletes who had graduated from here."

The aforementioned examples support Norman's (2010) recent findings encouraging social change of gender ideologies and inclusive environments, and present opportunities to change a cognitive institution (Leblebici et al., 1991). Throughout Dana's 17 career as an AD she has experienced some progressive changes. For example, Dana stated:

I think you have seen some really good changes, and part of that has come out of some leadership that the NCAA has also had, because many of the women that have also been involved in the NCAA have also been involved in those commissioner positions. And I do think people in the business are definitely more open minded from that aspect. It's just sometimes who's doing the hiring, whether they're board members or presidents and how progressive they really wanna be.

Since $17.9 \%$ of Fortune 1000 company's board members are females (2020WOB, 2015) and 26\% of collegiate presidents are female (Cook, 2012), Dana's question recognizes the progressive shift, while still upholds the concern for homosocial reproduction during the hiring process (Ramirez, 2004). Before hiring women may still be vetted on their gendered "fit" to work in an intercollegiate athletic department (e.g., flexible personal schedule, no young children, previous high level position, etc) (Burton, 2015). Abby noted a shift in the power of influence when she recalled being recruited five years ago for the AD position. She stated "What made me take this job though is when the head hunter called me and said 'I know you've wanted to run a football program as part of your career goals. How would you like to start one?"

Macro-Level Barriers. According to Shaw and Frisby (2006), it is important to recognize that gender shapes identities, while operating as an axis of power, structure, and processes in sport organizations. The power and institutionalization of men and masculinity was felt during Faith's press conference when a male reporter mentioned how she was a woman of firsts and asked "so how's this gonna work?" Faith laughingly responded with "I have no idea how it's gonna work. I've only been a women my whole entire life, like I don't know anything other than this."

The institutionalize practice of gender inequity (Cunningham, 2008) can be heard in another of Faith's curt examples, this time discussing her omission from the guest list at a donor golf outing. These golf outings are often used to raise money for the athletic arm of the institution, so when Faith was hired she knew 
donors "wanted to invite me, but this one guy who's in this group just flat out told me, ahh, you have the wrong plumbing." As she laughed, she continued to say "so they invited my husband to go with them." Faith's sarcastic reflection depicted the existence of a cognitive institution (Greenwood et al., 2002). For example, the idea of who plays and should play golf has "become taken-for-granted as the natural and appropriate arrangement" (Greenwood et al., 2002, p. 61) for men. Extending Walker and Sartore-Baldwin's (2013) research on institutionalized bias toward women, Faith's comment legitimized the notion that most people, specifically athletic donors and female ADs themselves, accept it as the way things are and cannot imagine the possibility of women playing golf. Faith's husband was upset at the proposal of him playing in her place, and at first did not want to participate, however, Faith understood that if she could not be there her husband must go in her place so she had representation at the event.

Although these female ADs may not be welcomed into the inner circles of fundraising within athletic departments, they are highly sought after to serve on committees both within and outside of their institutions. Due to the limited number of females in high level positions, nine year veteran AD, Bethany noted how "we [females] often get conned into a lot more service: board work, or NCAA committee work. While it's important, because they want to have diversity at the table, and if you look around there are a limited number, especially a limited number that have experience and so there tends to be the same cast of characters, myself being one."

In general, sport is considered to be an extremely masculine and gendered domain (Coakley, 2009). Despite increases in the number of female athletes, at all levels within sport, there has not been the same increase in female representation in athletic administration positions. Less than $25 \%$ of ADs are women across all three divisions of the NCAA, and that percentage drops to less than $10 \%$ at the NCAA Division I level. In addition, women working in intercollegiate athletics often describe experiencing difficulty working in a hostile, male-dominated environment (Norman, 2010). Women also commonly face unequal assumption of competence, hiring from a principle of similarity, homophobia, and lack of female mentors (Kamphoff, 2010; Kilty, 2006). Further, women have been stereotyped as not being as capable as leaders as men (Embry et al., 2008), and in the institute of sport male leadership and decision-making has become an acceptable norm (Whisenant et al., 2002).

\section{Meso-Level Factors}

The macro-level elements of gender are influenced and embedded in meso-level factors. Societal hegemonic masculine norms (Burton, 2015) create an organizational gender practice that is viewed as "institutionalized and widely recognized but also is dynamic, emergent, local, variable, and shifting" (Martin, 2003, p. 351). Therefore, to understand how interactional and structural levels contribute to gender inequity, an understanding of the practices of gender within organizations must be gained(Martin, 2003).

Meso-Level Supports. Historically, an informal gender-based group consisting of mostly White men characterized by exclusive and gender restrictive support systems, communication and hiring practices known as the "good old boys' network," (Acosta \& Carpenter, 2014; Lovett \& Lowry, 1994) has been progressing 
in intercollegiate athletics. More recently, Cunningham and Singer (2009) have revealed diverse and inclusive athletic department cultures are more likely to have historically under-represented individuals participate in mentoring activities to advance through the organizational hierarchy as well as proactive recruitment and hiring processes.

While every participant mentioned the historical prominence of the "good old boys' network", in Ilene's nine year experience as an AD, she has observed the following:

The good old boys club in intercollegiate athletics is slowly just becoming the good old club. As we have more and more women throughout intercollegiate athletic administration, we don't have a lot at the top, but we have women playing really critical roles.

Ellie echoes "the landscape has certainly changed and there is absolutely mutual respect and appreciation for the opinions of the females. At every level of administration we're all around the table."

While the same may not have been true 20 years ago, Cindy recalled the cognitive institute when she stated we would have "never seen a women walk around and be one [an AD]," and women were more likely to become a president of their institution than they were able to become an AD (Salter, 1996). Today, Abby acknowledges the increase of key constituents, female presidents, and in general believes "more and more presidents are giving female athletic administrators' opportunities, so that's improving." In 1986, only $10 \%$ of institutional leaders were women, however, in 2012 the percentage increased to $26 \%$ across the country (Cook, 2012). Similar to Cunningham and Singer (2009), recently hired AD, Kate, also noticed the shift to more inclusive initiatives and environments as "we're losing a lot of that original 'good old boys system' and you've got a new young AD. They're much more inclusive, so I think there's a shift going on."

This inclusive shift includes an organization with a welcoming family-friendly environment. Being a wife and former coach, Hannah "knows what it's like to be away from your family. I have the heart and understanding for coaches and coaches' families," which has helped her create a value of family within the department. In addition, wife and mother of two children, Faith noted "I love my kids growing up on campus, it's just the best. I mean my kids walk around campus, and they think they belong here, and the student-athletes and staff love them." Even with embracing family-friendly athletic environments, Faith notes her career achievements would not have been possible without a supportive partner.

It's really important that you have a partner that honors your lifestyle in athletics; that enjoys it, and wants to be part of it. It is a demanding lifestyle because it's nights and weekends, it's travel, ya know, it's a lot. And so it takes away from what you'd be doing with your partner, what you'd be doing with your family, so they must understand it is a place where you can grow and flourish.

According to our participants' views, the institutionalized organizational demography, structure, and culture of intercollegiate athletic administration is diversifying, which is shaped by those individuals within an organization (Weese, 1995), and influences those attracted to the place of employment (Cable, AimanSmith, Mulvey, \& Edwards, 2000). 
Meso-Level Barriers. Similar to barriers in a coaching lifestyle of women with a family and lack of encouragement from a partner or spouse (Thorngren, 1990), a common barrier is negotiating work and life (Bruening \& Dixon, 2007; LaVoi \& Dutove, 2012; Leberman \& LaVoi, 2011). This topic (i.e., the work-life interface for women within the industry of intercollegiate athletics) has been researched in great depth over the last decade (Dixon \& Bruening, 2005; Dixon \& Bruening, 2007; Dixon \& Sagas, 2007; Dixon, Tiell, Lough, Sweeney, Osborne, and Bruening, 2008). Comparable to the coaching lifestyle, Ellie knows the athletic administration lifestyle is "not conducive for families and these careers are tough, they can be very, very, very tough." Throughout Hannah's tenure she recalled a time as she was climbing the athletic administration ladder when her husband "was miserable and I knew that if we didn't leave town, it was just going to be really tough on my family." Bethany can also attest to the following:

I do this job 24/7, but I also do the mothering stuff 24/7. Being an AD is not a role I take off and put on, but it is who I am. No one cares, if you're married or not married, if you have kids or don't have kids, if you have old parents or a sick infant at home, they just want to know that you're going to do the job.

Research suggests that working in sport, particularly intercollegiate athletics can be described as a lifestyle rather than a job (Dixon \& Warner, 2010; Gaffney, Hardin, Fitzhugh, \& Koo, 2012). This challenge can be especially relevant for women because of the traditional societal norms that suggest women should be the primary caregiver of the family. Dixon and colleagues (2008) found that although institutions often offer a wide variety of work-life benefits for employees, female ADs and SWAs do not seem to take advantage of these benefits. This suggests that although the benefits are offered, the departmental culture may not be supportive of female ADs and/or SWAs using the benefits. In addition to family responsibilities, Kamphoff (2010) has noted females often leave the administrative profession early because of lack of time and support. The organizational demography and structure is still a hindrance for some institutions as Hannah noted "there wasn't anybody to look at, there wasn't any [female] role models." She knew she hit a ceiling and lacked support from her former AD when she went to him and said the following:

I really don't wanna leave here, but if I stay is my role going to change? Am I still going to have to sit at the scorer's table? Or have I worked to a point where I can get involved in fundraising and I can sit up in the stands and talk with donors and all that? And he looked at me and said, 'It's not gonna change.'

Until recently, work-life interface research in sport was analyzed mostly from the perspective of a mother working in intercollegiate athletics. However, new research from outside the sport industry suggested fathers may also perceive strain in the work and family relationship (Parker \& Wang, 2013). Within sport, it has been shown that male and female coaches encounter similar levels of overall work-life conflict that is derived from their attempts to succeed as both a coach and a father (Graham \& Dixon, 2017; Schenewark \& Dixon, 2012). Often times, the work-life conflict was created because work impeded on family time (Graham \& Dixon, 2017). This suggests that differences, if any, lie in the experiencing of and coping with these conflicts. This is especially important to note because prolonged 
work-life conflict, without proper coping mechanisms can lead to increased levels of dissatisfaction with roles in both family and work (Netemeyer, Boles, \& McMurrian, 1996).

This example of gender within an organizational structure and culture is linked to power (Ely \& Padavic, 2007). In collegiate athletics, men are overrepresented in higher paying and status jobs (Acosta \& Carpenter, 2014; Lapchick, 2015). Researchers have noted advancement opportunities may be limited for female athletic administrators who often lead soft support areas such as academic advising, women's sport oversight, and life skills programs, with inconsistent responsibility, particularly with decision-making authority (Cunningham, 2012; Lough \& Grappendorf, 2007; McDowell et al., 2009; Tiell, 2004; Whisenant et al., 2002). Seven of the ten participants indicated occupational segregation, which occurs when groups (i.e., women) are funneled into certain job positions (Jonung, 1984), constrained their advancement to senior level positions. Hannah thinks her "disadvantage was just not having the marketing, fundraising, business background," even in her 19-year career, "I never raised money, I was never called to raise money. I never built a building. I was strictly an event management person who supervised coaches." In addition, even throughout Hannah's career she has had oversight of 16 programs “everything except football and men's basketball, even at men's basketball I was helping with event management. At that time, ya know, for a female to have oversight of men's sport was unheard of." Such sentiments support Yiamouyiannis and Osborne's (2012) findings that revealed a lack of women athletic administrator representation on committees governing men's sports. In the cognitive institution of intercollegiate athletics (Walker and Sartore-Baldwin, 2013) the thought of change to have more women athletic administrators with men's sports' oversight, specifically football oversight, still cannot be fathomed.

To overcome these limitations, Faith adamantly stated "the bottom line is more women need to position themselves for opportunities... it's ahh up to us as women to position ourselves for that." Furthermore, Dana agrees females cannot "be afraid to ask for help, ask for more responsibility, ask for some guidance along the way." Without more exposure in highly visible areas women will not gain experience in positions that have been identified as important for AD hiring committees (Hardin et al., 2013).

\section{Microlevel Factors}

At the microlevel, individuals make meaning of their expectations and experiences, and understand how organizational policies and power operate (Burton, 2015). Individuals also try to explore psychological assumptions and self-limiting behaviors in the workplace (Burton, 2015; Cunningham, 2010).

Microlevel Supports. While no codified career path to becoming an AD exists (Grappendorf, Lough, \& Griffin, 2004), time after time, women have had to prove themselves in comparison with their male counterparts (Whisenant, 2003). According to Naughton (1998), it appears women are unlikely to be hired as an AD unless she has exceptional experience. Specifically in collegiate athletics, human and social capital differences have been instrumental to women's career advancement opportunities (Sagas \& Cunningham, 2004). When individuals accrue education, job experience, and training it is referred to as human capital, 
and when networks of relationships are built with supervisors, peers, and direct reports it is known as social capital (Sagas \& Cunningham, 2004).

Eight of the ten participants had been former collegiate coaches and they repeatedly mentioned how helpful that experience was to their career, which is similar to past findings of Tiell (2004) and Grappendorf and Lough (2004) who identified coaching as a key entry point for an athletic administrator's career. This "athletic capital" allows female ADs to relate to their coaches, both male and female, on a different level. The coaching experience allows AD to empathize with the challenges of being a collegiate coach. In addition, it helps ADs establish legitimacy in terms of knowledge about sport, coaching, and the NCAA. Former collegiate coach and 17 year veteran AD, Dana, thinks "one of the things that I like about where my background comes from is that I was a coach, and I do think that's unique sometimes when dealing with your coaches...you can relate to that piece." In agreement, former collegiate coach turned athletic administrator 15 years ago, Kate, noted how instrumental her coaching experience had been throughout her athletic administrative career. "Since I've been an administrator I don't think I've interacted with a coach without them starting everything they say with, 'I know you understand [Kate], because you coached'." Nine year veteran AD, Bethany, echoed the sentiments of the importance of coaching for females and brought to light the comparison with men when she stated the following:

I think any time you are an AD people want to know if you have played the sport, or coached the sport, and so I'm fortunate that I was a college athlete. However, there is the stereotype that most ADs that are male have never played college football, however, they never get that question. I think as a women, it just becomes more pronounced - well what do you know about football?

Similar to football oversight, Bethany's statement supports Walker and SartoreBaldwin's (2013) assertion that intercollegiate athletics is cognitive institution biased against women ADs. Particularly institutions with football continue to preserve the social norm of male ADs, thereby perpetuating male domination and masculinity (Whisenant et al., 2002).

Not only is having human capital important to female AD's career, but having social capital grants individuals more access to influence, information, and resources (Sagas \& Cunningham, 2005; Seibert et al., 2001). Putnam (1995) refers to social capital as the "features of social organization such as networks, norms, and social trust that can facilitate coordination and cooperation for mutual benefit" (p. 66). Having been in collegiate athletics for 30 years, Kate knows a key to success is "to reach out across the aisle in all kinds of directions. I've been in those social circles for a long time, you kind of don't get to this point without having those relationships." After a 19 year career in athletic administration, seven of which as the AD, Faith has an extended network of males and females. For example, depending on the situation Faith knows:

If I am dealing with something that is really gender specific, then I might call [list of three female ADs] and say, hey, gosh dang it, how have you handled this in the past? Or this is what I'm feeling, do I need to be making sense of this? Or how do you address that because I want a women's perspective. But if it's not, and I could go the other way, and call one of my guy friends, and 
say...I'm feeling this, am I just being an over reactive women because I'm so sensitive to this, or am I dealing with some stuff here where I need to get a better gender perspective.

Similarly, Ilene had a supportive network of females and she said "that they were fantastic, but I had great mentors in guys too." At 52 years old, Abby did not have as many female connections throughout her career, but "luckily I had fabulous male mentors." Not only are mentoring relationships important for career development and success (Ibarra, Carter, \& Silva, 2010), they are crucial for females working in male-dominated industries (Bower, 2009). In these maledominated industries, women often times do not have the same opportunities to climb the corporate ladder, network, or even receive mentorship as men, which makes creating these mentorship relationships incredibly important (Ruderman \& Ohlott, 2004). Mentoring relationships have also been found to aid in the balancing of work and personal life, which has been cited as a common struggle for both women and men working intercollegiate athletics (Eason, Mazerolle, \& Goodman, 2014). Male mentors have been known to provide more insight on career functions, while female mentors provide greater insight to the psychological function (Cullen \& Luna, 1993). As such, Abby encourages others to seek both male and female mentors, and knows there are more females "for young women coming up in their field to be able to get some guidance, which I think is critical."

Having the social capital is crucial to the favorable experience of female ADs. Not only knowing females, but also males makes for a more extensive social network. As such, researchers have reveled networks generally have an effect on both organizational success and individual careers (Ibarra, 1997). Knowing the close working relationship between an $\mathrm{AD}$ and football coach in a collegiate athletic department, Bethany's said "I was lucky at [University X], I worked very closely with football. Some of my references are former football coaches."

Faith believes her career has been successful because "there's a reason for women to connect and be connected and support one another and umm reach out to one another. I am a part of that network and proud to be a resource and I like that." In short, having these unique and diverse relationships are a central tenant of social capital because it enhances the female AD's access to valuable information (Lin, 2001).

Microlevel Barriers. With males occupying the majority of athletic administrative position at all levels of sport, being of female sex is "an immutable and inherent variable," (LaVoi \& Dutove, 2012, p. 23), and is often a barrier for athletic administrators or women wanting to enter athletic administration. Researchers have shown the likelihood that gender plays a role in probable and improbable career paths for females (Jacobs, 1999; Smith, 2002; Trentham \& Larwood, 1998). The range of acceptable career paths begins at age six during the gendered socialization process based on perceived ideologies and prestige (Gottfredson, 1981). Faith attested she "never sat down and said, I want to be an AD when I'm older." Gabby also never saw collegiate athletics as a career option, "I actually didn't really even think about working in collegiate athletics." Gabby agreed:

We're socialized that way, frankly from the time we're born there's a lot of people that take hits at women. They objectify women, a lot of things happen, 
and so that takes a toll on your confidence without even knowing it and I think we need to get people to operate with more confidence.

In addition to the influence gender socialization has on career choices, selfefficacy also has an impact (Hackett \& Betz, 1981). Gabby knows "you really have to believe in yourself. We have a void in confidence as a gender."

Seven year veteran AD, Faith, supports Sartore and Cunningham (2007) notion that "ideological gender beliefs may serve to inhibit women within sport organizations through internal identity comparison processes that may subsequently result in the unconscious manifestation of self-limiting behaviors" (p. 259) when she said the following:

We [females] have plenty of expertise, we've got the background, we've got education, we've got those things, what we need is confidence in who we are, what we're doing and that we're confident and competent to do the job, and we gotta own that. And then we gotta get out there and do it.

Earlier in Faith's career self-doubt and self-limitation was heard in her voice when she recalled a story before becoming an AD. When given an opportunity to lead a department, she recalled telling her former AD "I don't know how to do that!" and he responded with "yes you do, figure it out." Although Faith questioned her own abilities, her former AD was quick to support her with the necessary resources and motivation to reminder her that she was capable. Ellie also reflected on a time of self-doubt when she almost withheld her name from a promotion because "I was undecided if I was going to throw my hat in the ring to tell you the truth ... I figured, not because I didn't want it, but because it was just I knew who the president wanted to hire." Similarly, Gabby, limited herself by questioning, at times, whether she "had the stomach to deal with a lot of the tough things and the hard decisions AD's come across in their line of work." Personal judgment statements such as those listed above can predict one's ability to set goals, insistently pursue efforts, or attain expected outcomes (Bandura, 1986).

\section{Theoretical and Practical Implications}

The multilevel model provides several implications for scholars and practitioners alike. Although numerous descriptive studies have been conducted on the frequency and percentages of female coaches and administrators in intercollegiate athletics (see Acosta \& Carpenter, 2014; Lapchick, 2015), few scholars have examined athletic administrators, especially female ADs; due to the relatively small number of female ADs, this has been a hard to reach population. To better understand the experiences of women working in athletics, researchers have examined samples of women from positions of lesser authority. Research by Bower and Hums (2013) as well as Grappendorf et al. (2008) used survey methodology with open ended questions to better understand the experiences of female administrators, however their samples were comprised of women who identified as Associate Athletic Directors and Senior Woman Administrators. Hancock and Hums (2016) interviewed a sample of NCAA Division I female Senior Level Administrators about their career development, experiences, and goals; these women identified themselves as Assistant and Associate Athletic Directors. The qualitative nature of the study allowed the 
participants to tell their unique story during the interview and for the researchers to pull out unexpected themes (Gratton \& Jones, 2004), which provided analysis beyond raw numbers and gave insight into the work-lives of the small population of Division I female ADs.

Theoretically, the multilevel framework is a unique approach used by few researchers, and was the first to explicitly evaluate and gain an understanding into the workplace experiences of female NCAA Division I female ADs' barriers and supports. Recognizing the intersectionality of the multilevel factors provided a holistic understanding of why female ADs may be underrepresented, which is a significant and important conceptual contribution, given that scholars and practitioners have wrestled with the best way to address the underrepresentation of female leaders in intercollegiate athletics for decades. Furthermore, results from the model identified the embedded norms that can be shifted to create more inclusive workplace environments, and stimulate individuals to make a change to increase equality by reducing barriers and increasing supports.

In terms of practical implications, there are numerous application opportunities for individuals, organizations, and society. First, since each female participant mentioned how advantageous their human capital was to their pursuit of an AD position, it is imperative athletic administrators take more control of their future, if and when they are afforded the opportunity, and sponsor other individuals to create a pipeline of opportunities for advanced education, training, and experiences. In addition, similar to LaVoi and Dutove (2012), the model can assist the reflective practices of all female athletic administrators. For example, female athletic administrators should create conversations around gender norms and socialization practices that may limit their pursuit of career advancement. Further, individuals with decision-making power, which the majority represented in sport are men, need to provide mentorship, sponsorship, tools, and policies to educate and create inclusive climates. In particular, ADs, especially the majority male ADs, are in the position to be a sponsor because they hold a decision-making position and could use the platform to publicly support the advancement of females (Ibarra et al., 2010). In a sponsorship relationship, the sponsors work with protégés with the specific purpose of advancing their career (Wayne, Linden, Kraimer, \& Graf, 1999). A sponsor from inside the same organization as their protégé will recommend the protégé for promotions or projects. Therefore, a rising talented female is a high risk because a sponsor puts his or her reputation on the line and acts as an advocate for career growth (Harris, 2014). Providing such opportunities will allow diverse and inclusive environments to surface at the meso-level, which were noted by all participants. Diverse and inclusive environments will likely have greater representation of underrepresented groups, proactive recruitment and hiring processes (Cunningham \& Singer, 2009), which can be powered by stakeholder expectations.

Additional practical implications can be illustrated by examining the benefits of diversity in the workplace. Appreciation for diversity within an organization is characterized with respect for differences, orientation toward employees over tasks, and flexibility (Doherty, Fink, Inglis, \& Pastore, 2010). Positive outcomes of workplace diversity include decreased turnover (Chrobot-Mason \& Aramovich, 2013) and positive impact on organizational outcomes such as organizational effectiveness (Garib, 2013). On the other hand, previous research suggests underrepresented 
groups may encounter less positive work environments (i.e., lower levels of workplace comfort, productivity, and/or satisfaction) (Cunningham, 2007). Women working in organizations that are male dominated have been found to encounter a higher number of issues with unethical or unprofessional conduct due to the value placed on masculine characteristics such as power, dominance, and aggressiveness (Vogt, Bruce, Street, \& Strafford, 2007). It is therefore important to educate all employees on the benefits of embracing diversity in the workplace and accepting colleagues who may be of a different gender, race or ethnicity, religion, or ability. Embracing diversity and increasing inclusivity is crucial for organizational culture, as women working in these male dominated organizations often believe this harassment comes with the territory and position and become accepting of these toxic behaviors (McLaughlin, Uggen, \& Blackstone, 2009).

\section{Limitations}

Although there is a limited number of female NCAA Division I ADs, the current study only interviewed 10 of the 34 female Division I ADs. Interviewing 10 different ADs may produce different themes, but the researchers believe saturation was met. The interview transcripts could have been interpreted differently by other researchers or using other theoretical frameworks as well. The interviews were conducted via telephone as well, so the interviewer could not see the reactions or body language of the respondents to determine if the initial question should have received a follow-up based on the physical response of the respondent. Finally, although researchers deem that saturation was met, an average interview length of $27 \mathrm{~min}$ is short. Had researchers engaged with participants for a longer period of time, more specific details about experiences of supports and barriers may have emerged.

\section{Future Directions}

In this particular study, the multilevel approach examined the barriers and supports specific to NCAA Division I female ADs. The scarcity of females ADs and the salient gender stereotypes in athletic administration, or the sport industry in general, may create increased stereotype threats for females (Hoyt \& Murphy, 2016). Stereotype threats are judgments or treatments of negative stereotypes about a group. (Hoyt \& Murphy, 2016). As such, further research uncovering the effects of stereotype threat on individual's identity and leadership ability may be fruitful. In addition, a comparative research study from the perspective of male NCAA Division I ADs at all levels of analysis may help identify how the intersection of gender, race, sexual orientation, class, or disability influences the access to opportunities in sport leadership positions (Burton, 2015; Knoppers \& Anthonissen, 2008).

In general, there were very few support only factors revealed in this study. The overwhelming literature on barriers may have guided the direction of the interviews, so further insight, specific to supports, is warranted. In particular, further investigation into the lack of support at the macro level is necessary. Since ideologies of stakeholders can influence organizational practices (Burton, 2015; Cunningham, 2010), measuring the perceptions of these core constituents could provide deeper insight into expectations of sport leaders. 


\section{Conclusion}

The purpose of this study was to assess the supports and barriers experienced by female NCAA Division I ADs using a multilevel approach. While limited researchers have used a multilevel framework focused on coaches (Cunningham, 2010; LaVoi \& Dutove, 2012) and women in sport leadership (Burton, 2015), the model here is the first to explicitly recognize the barriers and supports of female ADs.

\section{References}

2020. WOB. (2015). Women on Boards' Gender Diversity Index. Retrieved from https:// www.2020wob.com/sites/default/files/2020GDI-2015Report.pdf

Acosta, R.V., \& Carpenter, L.J. (2014). Women in intercollegiate sport: A longitudinal, national study, thirty-seven year update-1977-2014. Unpublished manuscript. Available for downloading at www.acostacarpenter.org

Allison, G. (1971). Essence of decision: Explaining the Cuban missile crisis. Boston, MA: Little Brown.

Andrew, D., Pedersen, P., \& McEvoy, C. (2011). Research method and design in sport management. Champaign, IL: Human Kinetics.

Bandura, A. (1986). Social foundations of thought and action: A social cognitive theory. Englewood Cliffs, NJ: Prentice-Hall.

Bergman, M., \& Henning, J. (2008). Sex and ethnicity as moderators in the sexual harassment phenomenon: A revision and test of Fitzgerald et al. (1994). Journal of Occupational Health Psychology, 13(2), 152-167. PubMed https://doi.org/10.1037/10768998.13.2.152

Bolman, L., \& Deal, T. (2003). Reframing organizations: Artistry, choice, and leadership (3rd ed.). San Francisco: Josey-Bass.

Bower, G.G. (2009). Group mentoring as an alternative model for women. Women in Sport and Physical Activity Journal, 18(2), 80-84. https://doi.org/10.1123/wspaj.18.2.80

Bower, G.G., \& Hums, M.A. (2013). Career paths of women working in leadership positions within intercollegiate athletic administration. Advancing Women in Leadership, $33,1-14$.

Bruening, J.E., \& Dixon, M.A. (2007). Work-family conflict in coaching II: Managing role conflict. Journal of Sport Management, 21(4), 471-496. https://doi.org/10.1123/ jsm.21.4.471

Burton, L.J. (2015). Underrepresentation of women in sport leadership: A review of research. Sport Management Review, 18(2), 155-165. https://doi.org/10.1016/j.smr.2014.02.004

Burton, L., Barr, C.A., Fink, J.S., \& Bruening, J.E. (2009). "Think athletic director, think masculine?": Examination of the gender typing of managerial subroles within athletic administration positions. Sex Roles, 61(5-6), 416-426. https://doi.org/10.1007/s11199009-9632-6

Cable, D.M., Aiman-Smith, L., Mulvey, P.W., \& Edwards, J.R. (2000). The sources and accuracy of job applicants' beliefs about organizational culture. Academy of Management Journal, 43(6), 1076-1085. https://doi.org/10.2307/1556336

Cahn, S.K. (1994). Coming on strong: Gender and sexuality in twentieth century women's sport. New York, NY: Free Press.

Carpenter, L.J., \& Acosta, R.V. (1992). Job status: Reflections of immobility and resistance to job change among senior woman athletic personnel. Unpublished manuscript. Brooklyn College. Brooklyn, NY.

Chelladurai, P. (2014). Managing organization for sport and physical activity (4th ed.). Scottsdale, AZ: Holcomb Hathaway. 
Chrobot-Mason, D., \& Aramovich, N.P. (2013). The psychological benefits of creating an affirming climate for workplace diversity. Group \& Organization Management, 38(6), 659-689. https://doi.org/10.1177/1059601113509835

Creswell, J.W. (2013). Research design: Qualitative and quantitative approaches. Thousand Oaks, CA: Sage.

Coakley, J. (2009). Sports in society: Issues and controversies (10th ed.). Boston, MA: McGraw-Hill.

Cook, B.J. (2012). The American college president study: Key findings and takeaways. Washington DC: American Council on Education. Retrieved from http://www.acenet. edu/the-presidency/columns-and-features/Pages/The-American-College-PresidentStudy.aspx

Corbin, J., \& Strauss, A. (2008). Basics of Qualitative Research: Techniques and Procedures for Developing Grounded Theory. Thousand Oaks, California: SAGE Publications, Inc. https://doi.org/10.4135/9781452230153

Cullen, D.L., \& Luna, G. (1993). Women mentoring in academe: Addressing the gender gap in higher education. Gender and Education, 5(2), 125-137. https://doi. org/10.1080/0954025930050201

Cunningham, G.B., \& Sagas, M. (2002). The differential effects of human capital for male and female division I basketball coaches. Research Quarterly for Exercise and Sport, 73(4), 489-495. PubMed https://doi.org/10.1080/02701367.2002.10609051

Cunningham, G.B., \& Sagas, M. (2005). Access discrimination in intercollegiate athletics. Journal of Sport and Social Issues, 29(2), 148-163. https://doi.org/10.1177/0193723504271706

Cunningham, G.B. (2007). Diversity in sport organizations. Scottsdale, AZ: Holcomb, Hathaway.

Cunningham, G.B. (2008). Understanding diversity in intercollegiate athletics. Journal for the Study of Sports and Athletes in Education, 2(3), 321-338. https://doi.org/10.1179/ ssa.2008.2.3.321

Cunningham, G.B. (2010). Understanding the under-representation of African American coaches: A multilevel perspective. Sport Management Review, 13(4), 395-406. https:// doi.org/10.1016/j.smr.2009.07.006

Cunningham, G.B. (2012). Occupational segregation of African Americans in athletic administration. Wake Forest Journal of Law \& Policy, 2, 165-178.

Cunningham, G.B., \& Singer, J.N. (2009). Not all students are alike: Differences in the decision to enter the sport and leisure industry. International Journal of Sport Management, $10,350-365$.

DiMaggio, P. J. (1988). Interest and agency in institutional theory. In L. G. Zucker (Ed.), Institutional patterns and organizations: Culture and environment (3-21). Cambridge, MA: Ballinger.

Dittmore, S. (2011). Interviewing. In D.P.S. Andrew, P.M. Pedersen, \& C.D. McEvoy (Eds.), Research methods and design in sport management (pp. 91-104). Champaign, IL: Human Kinetics.

Dixon, M.A., \& Bruening, J.E. (2005). Perspectives of work-family conflict in sport: An integrated approach. Sport Management Review, 8(3), 227-253. https://doi.org/10.1016/ S1441-3523(05)70040-1

Dixon, M.A., \& Bruening, J.E. (2007). Work-family conflict in coaching I: A top-down perspective. Journal of Sport Management, 21(3), 377-406. https://doi.org/10.1123/ jsm.21.3.377

Dixon, M.A., \& Sagas, M. (2007). The relationship between organizational support, worklife conflict, and the job-life satisfaction of university coaches. Research Quarterly for Exercise and Sport, 78(3), 236-247. PubMed https://doi.org/10.1080/02701367.2007 .10599421

Dixon, M., Tiell, B., Lough, N., Sweeney, K., Osborne, B., \& Bruening, J. (2008). The work-life interface in intercollegiate athletics: An examination of policies, programs, 
and institutional climate. Journal for the Study of Sports and Athletes in Education, 2(2), 137-159. https://doi.org/10.1179/ssa.2008.2.2.137

Dixon, M.A., \& Warner, S. (2010). Employee Satisfaction in Sport: Development of a MultiDimensional Model in Coaching. Journal of Sport Management, 24(2), 139-168. https:// doi.org/10.1123/jsm.24.2.139

Doherty, A., Fink, J., Inglis, S., \& Pastore, D. (2010). Understanding a culture of diversity through frameworks of power and change. Sport Management Review, 13(4), 368-381. https://doi.org/10.1016/j.smr.2010.01.006

Eason, C.M., Mazerolle, S.M., \& Goodman, A. (2014). Motherhood and work-life balance in the National Collegiate Athletic Association Division I setting: Mentors and the female athletic trainer. Journal of Athletic Training, 49(4), 532-539. PubMed https:// doi.org/10.4085/1062-6050-49.3.03

Embry, A., Padgett, M.Y., \& Caldwell, C.B. (2008). Can leaders step outside the box? An examination of leadership and gender role stereotypes. Journal of Leadership \& Organizational Studies, 15(1), 30-45. https://doi.org/10.1177/1548051808318412

Ely, R., \& Padavic, I. (2007). A Feminist Analysis of Organizational Research on Sex Differences. Academy of Management Review, 32(4), 1121-1143. https://doi.org/10.5465/ AMR.2007.26585842

Forrest, M. L., \& Dougherty, T. W. (2004). Networking behaviors and career outcomes: Differences for men and women? Journal of Organizational Behavior, 25, 419-437.

Freeman, R.E. (1984). Strategic management: A stakeholder approach. Boston: Pitman.

Gaertner, S.L., Mann, J., Murrell, A., \& Dovidio, J.F. (1989). Reducing intergroup bias: The benefits of recategorization. Journal of Personality and Social Psychology, 57(2), 239-249. https://doi.org/10.1037/0022-3514.57.2.239

Gaffney, B., Hardin, R., Fitzhugh, E., \& Koo, G. (2012). The relationship between job satisfaction and burnout in certified athletic trainers. International Journal of Sport Management, 13(1), 73-86.

Garib, G. (2013). Leisure managers' perceptions of employee diversity and impact of employee diversity. International Journal of Hospitality Management, 32, 254-260. https://doi. org/10.1016/j.ijhm.2012.07.002

Gottfredson, L.S. (1981). Circumscription and compromise: A developmental theory of occupational aspirations. Journal of Counseling Psychology, 28(6), 545-579. https://doi. org/10.1037/0022-0167.28.6.545

Graham, J. A., \& Dixon, M. A. (2017). Work-family balance among coach-fathers: A qualitative examination of enrichment, conflict, and role management strategies. Journal of Sport Management, 31(3), 288-305.

Grappendorf, H., Pent, A., Burton, L., \& Henderson, A. (2008). Gender role stereotyping: A qualitative analysis of senior woman administrators' perceptions regarding financial decision-making. Journal of Issues in Intercollegiate Athletics, 1, 26-45.

Grappendorf, H., \& Lough, N. (2004). Reaching for the top? Senior Women Administrator: Profiles and career aspirations. Salem, Massachusetts: Salem State College. Albuquerque, NM: New Mexico University.

Grappendorf, H., \& Lough, N. (2006). An endangered species: Characteristics and perspectives from female NCAA Division I athletic directors of both separate and merged athletic departments. The Sport Management and Related Topics Journal, 2(2), 6-20.

Grappendorf, H., Lough, N., \& Griffin, J. (2004). Profiles and career patterns female NCAA division I athletic directors. International Journal of Sport Management, 5, 243-261.

Gratton, C., \& Jones, I. (2004). Research methods for sports studies. London: Routledge.

Greenhaus, J.H., Parasuraman, S., \& Wormley, W.M. (1990). Effects of race on organizational experience, job performance evaluations, and career outcomes. Academy of Management Journal, 33(1), 64-86. https://doi.org/10.2307/256352 
Greenwood, R., Suddaby, R., \& Hinings, C.R. (2002). Theorizing change: The role of professional associations in the transformation of institutionalized fields. Academy of Management Journal, 45, 58-80.

Greenwood, R., Oliver, C., Sahlin, K., \& Suddaby, R. (2008). The Sage handbook of organizational institutionalism. Los Angeles: Sage.

Gubrium, J.F., \& Holstein, J.A. (2001). Handbook of interview research:context \& method. Thousand Oaks, CA: SAGE Publications, Inc. https://doi.org/10.4135/9781412973588

Hackett, G., \& Betz, N.E. (1981). A self-efficacy approach to the career development of women. Journal of Vocational Behavior, 18(3), 236-399. https://doi.org/10.1016/00018791(81)90019-1

Hancock, M.G., \& Hums, M.A. (2016). A "leaky pipeline"?: Factors affecting the career development of senior-level female administrators in NCAA Division I athletic departments. Sport Management Review, 19(2), 198-210. https://doi.org/10.1016/j. smr.2015.04.004

Hardin, R., Cooper, C., \& Huffman, L. (2013). Moving on up: Division I athletic directors' career progression and involvement. Journal of Applied Sport Management, 5(3), 55-78.

Harris, J. (2014). She breaks into the inner sanctum of top management, with his sponsorship. Retrieved from https://www.linkedin.com/pulse/20140325211506-275490660-shebreaks-into-the-inner-sanctum-of-top-management-with-his-sponsorship

Hoffman, J. (2010). The dilemma of the senior woman administrator role in intercollegiate athletics. Journal of Issues in Intercollegiate Athletics, 3, 53-75.

Hovden, J. (2000). "Heaveyweight" men and younger women? The gendering of selection processes in Norwegian sport organizations. NORA. NORA, 14(1), 41-53.

Hoyt, C.L., \& Murphy, S.E. (2016). Managing to clear the air: Stereotype threat, women, and leadership. The Leadership Quarterly, 27(3), 387-399. https://doi.org/10.1016/j. leaqua.2015.11.002

Ibarra, H. (1997). Paving an alternative route: Gender differences in managerial network. Social Psychology Quarterly, 60(1), 91-102. https://doi.org/10.2307/2787014

Ibarra, H., Carter, N.C., \& Silva, C. (2010). Why men still get more promotions than women? Harvard Business Review, 80-85. PubMed

Inglis, S., Danylchuk, K.E., \& Pastore, D.L. (2000). Multiple realities of women's work experiences in coaching and athletic management. Women in Sport and Physical Activity Journal, 9(2), 1-14. https://doi.org/10.1123/wspaj.9.2.1

Jacobs, S. (1999). Trends in women's career patterns and gender in occupational mobility in Britain. Gender, Work and Organization, 6(1), 32-46. https://doi.org/10.1111/14680432.00067

Jonung, C. (1984). Patters of occupational segregation by sex in the labor market. In G. Schmid \& R. Weitzel (Eds.), Sex discrimination and equal opportunity (pp. 44_68). New York, NY: St. Martin's.

Kamphoff, C.S. (2010). Bargaining with patriarchy: Former female coaches' experiences and their decision to leave collegiate coaching. Research Quarterly for Exercise and Sport, 81, 360-372. PubMed

Kanter, R.M. (1977). Men and Women of the Corporation. New York: Basic Books.

Kilty, K. (2006). Women in coaching. The Sport Psychologist, 20(2), 222-234. https://doi. org/10.1123/tsp.20.2.222

Klein, K.J., \& Kozlowski, S.W.J. (2000). Multilevel theory, research, and methods in organizations. San Francisco: Jossey-Bass.

Knoppers, A., \& Anthonissen, A. (2008). Gendered managerial discourses in sport organizations: Multiplicity and complexity. Sex Roles, 58(1-2), 93-103. https://doi.org/10.1007/ s11199-007-9324-z

Kolnes, L. (1995). Heterosexuality as an organizing principle in women's sport. International Review for the Sociology of Sport, 30(1), 61-77. https://doi.org/10.1177/ 101269029503000104 
Konrad, A. M., Yang, Y., \& Maurer, C. C. (2016). Antecedents and outcomes of diversity and equality management systems: An integrated institutional agency and strategic human resource management approach. Human Resource Management, 55(1), 83-107.

Kozlowski, S. W. J., \& Klein, K. J. (2000). A multilevel approach to theory and research in organizations: Contextual, temporal, and emergent processes. In K. J. Klein \& S. W. J. Kozlowski (Eds.), Multilevel theory, research and methods in organizations: Foundations, extensions, and new directions (pp. 3-90). San Francisco, CA: Jossey-Bass.

Lapchick, R.E. (2015). The 2015 racial and gender report card: College sport. Orlando, FL: University of Central Florida, College of Business., Retrieved from http://nebula. wsimg.com/5050ddee56f2fcc884660e4a03297317?AccessKeyId=DAC3A56D8FB7 82449D2A\&disposition=0\&alloworigin $=1$.

LaVoi, N.M., \& Dutove, J.K. (2012). Barriers and supports for female coaches: An ecological model. Sports Coaching Review, 1(1), 17-37. https://doi.org/10.1080/2164 0629.2012 .695891

Leberman, S., \& LaVoi, N.M. (2011). Juggling balls and roles, mother-coaches in youth sport: Beyond the dualistic mother-worker identity. Journal of Sport Management, 25(5), 474-488. https://doi.org/10.1123/jsm.25.5.474

Leblebici, H., Salancik, G.R., Copay, A., \& King, T. (1991). Institutional change and the transformation of interorganizational fields: An organizational history of the U.S. radio broadcasting industry. Administrative Science Quarterly, 36(3), 333-363. https://doi.org/10.2307/2393200

Lin, N. (2001). Building a network theory of social capital. In N. Lin, K. Cook, \& R.S. Burt (Eds.), Social capital: Theory and research (pp. 3-29). New York: Aldine De Gruyter. https://doi.org/10.1017/CBO9780511815447.002

Lindlof, T.R., \& Taylor, B.C. (2011). Qualitative communication research methods. Thousand Oaks, CA: Sage Publication, Inc.

Longman, J. (2014). Amid cheers, union bid stirs concern for women. New York Times, 163(56461), B12-B13.

Lough, N., \& Grappendorf, H. (2007). Senior woman administrator's perspectives on professional advancement. International Journal of Sport Management, 8, 193-209.

Lovett, D.J., \& Lowry, C.D. (1994). Good old boys and good old girls clubs: Myth or reality? Journal of Sport Management, 8(1), 27-35. https://doi.org/10.1123/jsm.8.1.27

Lyness, K.S., \& Thompson, D.E. (2000). Climbing the corporate ladder: Do female and male executives follow the same route? The Journal of Applied Psychology, 85(1), 86-101. PubMed https://doi.org/10.1037/0021-9010.85.1.86

Martin, P.Y. (2003). Said and done versus saying and doing gendering practices, practicing gender at work. Gender \& Society, 17(3), 342-366. https://doi. org/10.1177/0891243203017003002

Maume, D.J., Jr. (1999). Glass ceilings and glass escalators: Occupational segregation and race and sex differences in managerial promotions. Work and Occupations, 26(4), 483-509. https://doi.org/10.1177/0730888499026004005

McDowell, J., \& Cunningham, G. (2007). The prevalence of occupational segregation in athletic administrative positions. International Journal of Sport Management, 8, $245-262$.

McDowell, J., Cunningham, G.B., \& Singer, J.N. (2009). The supply and demand side of occupational segregation: The case of an intercollegiate athletic department. Journal of African American Studies, 13(4), 431-454. https://doi.org/10.1007/s12111-0089057-2

McLaughlin, H., Uggen, C., \& Blackstone, A. (2009). Sexual harassment, workplace authority, and the paradox of power (Unpublished manuscript). University of Minnesota, Minneapolis, MN. 
Shaw, S., \& Frisby, W. (2006). Can gender equity be more equitable? Promoting an alternative frame for sport management research, education, and practice. Journal of Sport Management, 20(4), 483-509. https://doi.org/10.1123/jsm.20.4.483

Smith, M., \& Wrynn, A. (2013). Women in the 2012 Olympic and Paralympic games: An analysis of participation and leadership opportunities. Ann Arbor, MI: SHAPR Center for Women and Girls., Retrieved from http://irwg.research.umich.edu/pdf/Olympic_ Report_2012_FINAL\%204.11.13.pdf.

Smith, R.A. (2002). Race, gender, and authority in the workplace: Theory and research. Annual Review of Sociology, 28(1), 509-542. https://doi.org/10.1146/annurev. soc.28.110601.141048

Stangl, J.M., \& Kane, M.J. (1991). Structural variables that offer explanatory power for the underrepresentation of women coaches since Title IX: The case of homologous reproduction. Sociology of Sport Journal, 8(1), 47-60. https://doi.org/10.1123/ssj.8.1.47

Sutherland, L.M., Kowalski, K.C., Ferguson, L.J., Sabiston, C.M., Sedgwick, W.A., \& Crocker, P.R.E. (2014). Narratives of young women athletes' experiences of emotional pain and self-compassion. Qualitative Research in Sport, Exercise and Health, 6(4), 499-516. https://doi.org/10.1080/2159676X.2014.888587

Thorngren, C.M. (1990). A time to reach out: Keeping the female coach in coaching. Journal of Physical Education, Recreation \& Dance, 61(3), 57-60. https://doi.org/10.1080/073 03084.1990.10606478

Tiell, B. (2004). Career paths, roles, and tasks of senior woman administrators in intercollegiate athletics. Retrieved from ProQuest Digital Dissertations.

Trentham, S., \& Larwood, L. (1998). Gender discrimination and the workplace: An examination of rational bias theory. Sex Roles, 38(1/2), 1-27. https://doi.org/10.1023/A:1018782226876

Vogt, D., Bruce, T., Street, A., \& Strafford, J. (2007). Attitudes toward women and tolerance for sexual harassment among reservists. Violence Against Women, 13(9), 879-900. PubMed https://doi.org/10.1177/1077801207305217

Walker, N.A., \& Melton, E.N. (2015). The tipping point: The intersection of race, gender, and sexual orientation in intercollegiate sports. Journal of Sport Management, 29(3), 257-271. https://doi.org/10.1123/jsm.2013-0079

Walker, N.A., \& Sartore-Baldwin, M.L. (2013). Hegemonic masculinity and the institutionalized bias toward women in men's collegiate basketball: What do men think? Journal of Sport Management, 27(4), 303-315. https://doi.org/10.1123/jsm.27.4.303

Washington, M., \& Patterson, K.D.W. (2011). Hostile takeover or joint venture: Connections between institutional theory and sport management research. Sport Management Review, $14,1-12$.

Wayne, S.J., Linden, R.C., Kraimer, M.L., \& Graf, I.K. (1999). The role of human capital, motivation and supervisor sponsorship in predicting career success. Journal of Organizational Behavior, 20(5), 577-595. https://doi.org/10.1002/(SICI)10991379(199909)20:5<577::AID-JOB958>3.0.CO;2-0

Weese, W.J. (1995). Leadership and organizational culture: An investigation of Big Ten and Mid-American Conference campus recreation administrations. Journal of Sport Management, 9(2), 119-134. https://doi.org/10.1123/jsm.9.2.119

Whisenant, W.A. (2003). How women have fared as interscholastic athletic administrators since the passage of Title IX. Sex Roles, 49(3/4), 179-184. https://doi. org/10.1023/A:1024417115698

Whisenant, W.A., Pedersen, P.M., \& Obenour, B.L. (2002). Success and gender: Determining the rate of advancement for intercollegiate athletic directors. Sex Roles, 47(9/10), 485-491. https://doi.org/10.1023/A:1021656628604

Yiamouyiannis, A., \& Osborne, B. (2012). Addressing gender inequities in collegiate sport examining female leadership representation within NCAA sport governance. SAGE Open, 2(2), 1-13. https://doi.org/10.1177/2158244012449340

Yin, R. (1994). Case study research: Design and methods. London: Sage. 